\title{
Carnitine and Liver Functions Assessment in Children Treated with Anticonvulsant Drugs
}

\author{
SOAD M. ABDEl-GHANY, PhD*, TAHIA H. SALEEM, PhD**, \\ MOHAMMED M.H. GHAZALY, PhD ${ }^{* * *}$ and NAGLA T. El-MELEGY, $\mathrm{PhD}^{* *}$ \\ *Department of Biochemistry, Faculty of Medicine and Allied Sciences, King Abdulaziz \\ University, Jeddah, Saudi Arabia and Departments of ${ }^{* *}$ Biochemistry \\ and ${ }^{* * *}$ Pediatrics, Faculty of Medicine, Assiut University, Assiut, Egypt
}

\begin{abstract}
This study was conducted to evaluate the impact of antiepileptic drugs on the liver function and L-carnitine levels in children suffering from epilepsy. Sixty epileptic children aged from 1 to 15 years, together with 20 healthy controls were studied. Among them twenty-five children were treated with phenytoin (group I), 25 were treated with carbamazepine (group II) and 10 patients were treated with phenobarbital (group III). In each of the three groups, serum free carnitine levels were significantly decreased after one month of therapy compared with pretherapy levels $(\mathrm{p}<0.01, \mathrm{p}<0.01, \mathrm{p}<0.01 \mathrm{re}-$ spectively). Meanwhile, the levels of L-carnitine in treated children collectively were significantly decreased in comparison with healthy children $(\mathrm{p}<0.01)$. Hypocarnitinemia was detected in $28 \%$ of group I, $56 \%$ of group II , and $30 \%$ of group III. Serum SGOT was significantly increased in patients treated with phenytoin and phenobarbital ( $\mathrm{p}<0.01, \mathrm{p}<0.05$ respectively) compared with pretherapy levels. Whereas serum lactate and total bilirubin were significantly increased after therapy in patients treated with carbamazepine in comparison to that before significantly increased ( $\mathrm{p}<0.05$ for each) in comparison with controls. Moreover, a significant negative correlation was found between values of carnitine and both lactate $(\mathrm{p}<0.01)$ and lactate/pyruvate ratio $(\mathrm{p}<0.05)$ after therapy in carbamazepine treated group. It should be taken into account that carnitine rich food in the form of milk and milk products must be taken as a supplement to the antiepileptic drugs especially carbamazepine.
\end{abstract}

Keywords: Carnitine, Liver functions, Epileptic children, Anticonvulsants.

Correspondence \& reprint requests to: Dr. Soad M. Abdel-Ghany, P.O. Box 80205, Jeddah 21589, Saudi Arabia.

Accepted for publication: 26 October 1998. Received: 18 November 1997. 


\section{Introduction}

Epilepsy has been defined as a paroxysmal disorder of the nervous system characterized by recurrent attacks usually with alteration of consciousness with or without convulsive movement ${ }^{[1]}$.

The most effective method for the control of seizures is the use of anticonvulsive drugs, namely phenobarbital (Mebaral), phenytoin (Dilantin), epamin (Epanutin), mephenytoin (Mesantoin), primidon (Mysoline), carbamazepine (Tegretol), ethosuximide (Zarontin), and valproic acid (depakene) ${ }^{[2]}$. All of these drugs are known to cause adverse effects.

A serious Reye-like syndrome involving stupor, coma, hepatic dysfunction, and hyperammonemia has been attributed to valproate (VPA) ${ }^{[3-5]}$. Patients taking VAP with phenytoin and phenobarbitone had significantly higher plasma ammonia levels ${ }^{[6-8]}$ and significantly lower carnitine levels than did patients on phenytoin and phenobarbitone alone $^{[6,8]}$. Coulter and Allen ${ }^{[5]}$ proposed carbamoyl-phosphate synthetase deficiency as a cause of hyperammonemia while Coud et $a l^{[9]}$ attributed valproate induced hyperammonemia to an inhibited $\mathrm{N}$-acetylglutamate synthesis. Valproate is found to be toxic to rat liver-mitochondria in both in vitro ${ }^{[10]}$ and in vivo ${ }^{[11]}$. Valproate can inhibit mitochondrial $\beta$-oxidation of long-chain fatty acids by formation of valproyl-Co A that sequesters free Co $\mathrm{A}^{[12,13]}$. In addition, valproate metabolites can inhibit enzymes involved in $\beta$-oxidation $^{[14]}$ and exacerbate carnitine deficiency ${ }^{[15]}$.

More recently, it has been observed that VAP causes a decrease in the level of Lglutamate and L-ketoglutarate, a cofactor of butyrobetaine-hydroxylase in liver that is essential for carnitine formation ${ }^{[16]}$. Severe tissue carnitine deficiency might result in severe illness as a Reye-like syndrome and even fatal hepatotoxicity ${ }^{[17]}$ due to the impaired mitochondrial metabolism in liver and the release of hepatotoxic metabolites into circulation $^{[13]}$. Segade et al ${ }^{[18]}$ detected hypocarnitinemia in $21.5 \%$ of the non-VAP patients (those taken phenytoin, carbamazepine, and/or phenobarbital as anticonvulsants) ranging from 15.4 to $26.8 \%$. Bates and $\mathrm{Hug}^{[19]}$ found that the lowest carnitine levels were among patients taking phenobarbital drug.

Therefore, the detection of these side effects is of great importance as these drugs will be used by the patient for a long time, especially with drugs causing hepatotoxicity like valproate. That is why liver function tests must be performed regularly for early detection of these side effects ${ }^{[13]}$. This study aims at evaluating the effects of the three most commonly used drugs, namely, phenytoin, carbamazepine, and phenobarbital on the liver function as independent variables and L-carnitine as a dependent variable in children suffering from epilepsy.

\section{Materials and Methods}

This study involved 60 outpatients from the Assiut University Pediatric Clinic who 
had been diagnosed as epileptic, aged 1-15 years (mean \pm SD: $8.76+4.09)(36$ males and 24 females) and 20 apparently healthy controls (10 males and 10 females of the same age group $(7.77+4.07))$ and from the same geographical distribution.

All the epileptic children were free from any affecting disease and mental or motor disabilities; their fundus examination was normal. They had been diagnosed as primary generalized tonic-clonic epilepsy (grand mal) according to clinical history and electro-encephalograph records. They were treated with anticonvulsant drugs for the first time. Based on the drug used, they were divided into three groups. The first group consisted of 25 patients treated with phenytoin in a dose of $4-8 \mathrm{mg} / \mathrm{kg} / \mathrm{day}$, the second group consisted of 25 patients treated with carbamazepine in a dose of $10-30 \mathrm{mg} / \mathrm{kg}$ / day, and the third group consisted of 10 patients treated with phenobarbital in a dose of $1-5 \mathrm{mg} / \mathrm{kg} / \mathrm{day}$. The drug was administered two times per day while the drug dosage varied according to the patient's age. As there was no facility for us to measure the drug plasma concentration, we used the maximum tolerated dose as indicated.

During the period of the study, the patients and controls received a normal balanced diet according to their age and nutritional requirements. Patients having evidence of malnutrition were not included in the study. Two samples of blood were taken from each patient, one before the start of the treatment (at 0 day) and the second after the treatment by one month (30 days). No patient had changed his drug or dosage during the period of the study. Blood samples were centrifuged and the sera were separated and kept deep frozen at $-20^{\circ} \mathrm{C}$ until analysis.

The sera of patients and controls were tested for:

* free L-carnitine by the enzymatic UV assay kit purchased from Boehringer Mannhim, France

* transaminases activity (GOT and GPT) colorimetically according to Reitman and Frankel method ${ }^{[20]}$

* triglycerides by an enzymatic method using triglycerides enzymatique PAP kit purchased from bioMerieux, France

* total bilirubin by the use of bilirubin and ictotrol kit purchased from bioMerieux, France

* lactate and pyruvate levels according to the method of Marbach and Weil ${ }^{[21]}$

Statistical Analysis: The statistical significance of differences between two groups was assessed by using student's $t$-test. The correlations between variables were evaluated by linear regression analysis or by correlation coefficient. Differences were accepted as statistically significant when $\mathrm{P}<0.05$.

\section{Results}

The mean (X) and standard deviation (SD) of various parameters studied in sera of phenytoin treated group (I), carbamazepine treated group (II), and phenobarbital treated group (III) before and after therapy are shown in Tables 1 and 2. 
TABLE 1. The mean \pm SD of the various parameters studied in the sera of all epileptic groups before therapy in comparison to controls.

\begin{tabular}{|c|c|c|c|c|}
\hline Parameter & $\begin{array}{l}\text { Controls } \\
(\mathrm{n}=20)\end{array}$ & $\begin{array}{l}\text { Group I } \\
\text { Phenytoin } \\
(\mathrm{n}=25)\end{array}$ & $\begin{array}{c}\text { Group II } \\
\text { Carbamazepine } \\
(\mathrm{n}=25)\end{array}$ & $\begin{array}{c}\text { Group III } \\
\text { Phenobarbital } \\
(\mathrm{n}=10)\end{array}$ \\
\hline Free carnitine $(\mu \mathrm{mol} / \mathrm{L})$ & $44.50 \pm 2.42$ & $\begin{array}{c}48.91 \pm 12.93 \\
\text { p1 N.S. }\end{array}$ & $\begin{array}{l}44.86 \pm 11.10 \\
\text { p1 N.S. } \\
\text { p2 N.S. }\end{array}$ & $\begin{array}{l}48.20 \pm 8.56 \\
\text { p1 N.S. } \\
\text { p2 N.S. } \\
\text { p3 N.S. }\end{array}$ \\
\hline SGOT $(\mathrm{U} / \mathrm{ml})$ & $20.45 \pm 3.30$ & $\begin{array}{c}19.75 \pm 2.17 \\
\text { p1 N.S. }\end{array}$ & $\begin{array}{c}20.80 \pm 2.318 \\
\text { p1 N.S. } \\
\text { p2 N.S. }\end{array}$ & $\begin{array}{l}19.39 \pm 1.51 \\
\text { p1 N.S. } \\
\text { p2 N.S. } \\
\text { p3 N.S. }\end{array}$ \\
\hline SGPT $(\mathrm{U} / \mathrm{ml})$ & $19.87 \pm 1.16$ & $\begin{array}{c}19.430 \pm 1.99 \\
\text { p1 N.S. }\end{array}$ & $\begin{array}{c}20.14 \pm 2.79 \\
\text { p1 N.S. } \\
\text { p2 N.S. }\end{array}$ & $\begin{array}{c}18.00 \pm 1.92 \\
\text { p1 N.S. } \\
\text { p2 N.S. } \\
\text { p3 N.S. }\end{array}$ \\
\hline Triglycerides $(\mathrm{mmol} / \mathrm{L})$ & $1.10 \pm 0.30$ & $\begin{array}{c}1.18 \pm 0.29 \\
\text { p1 N.S. }\end{array}$ & $\begin{array}{c}1.22 \pm 0.37 \\
\text { p1 N.S. } \\
\text { p2 N.S. }\end{array}$ & $\begin{array}{l}1.05 \pm 0.51 \\
\text { p1 N.S. } \\
\text { p2 N.S. } \\
\text { p3 N.S. }\end{array}$ \\
\hline Total bilirubin $(\mu \mathrm{mol} / \mathrm{L})$ & $8.24 \pm 3.59$ & $\begin{array}{c}10.24 \pm 4.35 \\
\text { p1 N.S. }\end{array}$ & $\begin{array}{l}9.05 \pm 4.14 \\
\text { p1 N.S. } \\
\text { p2 N.S. }\end{array}$ & $\begin{array}{c}10.21 \pm 4.27 \\
\text { p1 N.S. } \\
\text { p2 N.S. } \\
\text { p3 N.S. }\end{array}$ \\
\hline Pyruvate $(\mathrm{mmol} / \mathrm{L})$ & $0.05 \pm 0.02$ & $\begin{array}{c}0.06 \pm 0.02 \\
\text { p1 N.S. }\end{array}$ & $\begin{array}{l}0.05 \pm 0.01 \\
\text { p1 N.S. } \\
\text { p2 N.S. }\end{array}$ & $\begin{array}{l}0.05 \pm 0.01 \\
\text { p1 N.S. } \\
\text { p2 N.S. } \\
\text { p3 N.S. }\end{array}$ \\
\hline Lactate $(\mathrm{mmol} / \mathrm{L})$ & $0.82 \pm 0.33$ & $\begin{array}{l}0.86 \pm 0.21 \\
\text { p1 N.S. }\end{array}$ & $\begin{array}{c}0.74 \pm 0.25 \\
\text { p1 N.S. } \\
\text { p2 N.S. }\end{array}$ & $\begin{array}{l}0.75 \pm 0.31 \\
\text { p1 N.S. } \\
\text { p2 N.S. } \\
\text { p3 N.S. }\end{array}$ \\
\hline Lactate:pyruvate ratio & $18.07 \pm 9.57$ & $\begin{array}{c}16.29 \pm 5.87 \\
\text { p1 N.S. }\end{array}$ & $\begin{array}{c}15.87 \pm 7.44 \\
\text { p1 N.S. } \\
\text { p2 N.S. }\end{array}$ & $\begin{array}{c}15.78 \pm 6.79 \\
\text { p1 N.S. } \\
\text { p2 N.S. } \\
\text { p3 N.S. }\end{array}$ \\
\hline
\end{tabular}

p1: groups versus controls

p2: phenytoin versus other groups

p3: carbamazepine versus phenobarbital group

Group I (Phenytoin Treated Cases): The patients had a significantly lower mean \pm $\mathrm{SD}$ values of serum free carnitine after therapy than that before therapy $(\mathrm{P}<0.01)$. Among them, seven cases showed decreased values (28\%) after treatment whereas the mean \pm SD values of SGOT after therapy were significantly higher (incidence is $4 \%$ ) than that before therapy $(\mathrm{P}<0.01)$. The values of total bilirubin after therapy were significantly higher (incidence is $20 \%)$ than both pretherapy level $(\mathrm{P}<0.05)$ and the control level $(\mathrm{P}<0.01)$. In this group the values of triglycerides before and after therapy are significantly correlated to the values of lactate $(\mathrm{P}<0.01$ and $\mathrm{P}<0.05$, respectively).

Group II (Carbamazepine Treated Cases): The mean \pm SD value of serum free 
TABLE 2. The mean \pm SD of the various parameters studied in the sera of all epileptic groups after therapy in comparison to controls.

\begin{tabular}{|c|c|c|c|c|}
\hline Parameter & $\begin{array}{l}\text { Controls } \\
(\mathrm{n}=20)\end{array}$ & $\begin{array}{l}\text { Group I } \\
\text { Phenytoin } \\
(\mathrm{n}=25)\end{array}$ & $\begin{array}{c}\text { Group II } \\
\text { Carbamazepine } \\
(\mathrm{n}=25)\end{array}$ & $\begin{array}{c}\text { Group III } \\
\text { Phenobarbital } \\
(\mathrm{n}=10)\end{array}$ \\
\hline Free carnitine $(\mu \mathrm{mol} / \mathrm{L})$ & $44.50 \pm 2.42$ & $\begin{array}{c}40.479 \pm 13.55 \\
\text { p1 N.S. }\end{array}$ & $\begin{array}{c}35.50 \pm 11.48 \\
\text { p1 }<0.01 \\
\text { p2 N.S. }\end{array}$ & $\begin{array}{l}41.06 \pm 12.49 \\
\text { p1 N.S. } \\
\text { p2 N.S. } \\
\text { p3 N.S. }\end{array}$ \\
\hline SGOT (U/ml) & $20.45 \pm 3.30$ & $\begin{array}{c}21.00 \pm 2.36 \\
\text { p1 N.S. }\end{array}$ & $\begin{array}{c}21.12 \pm 2.34 \\
\text { p1 N.S. } \\
\text { p2 N.S. }\end{array}$ & $\begin{array}{l}20.01 \pm 1.80 \\
\text { p1 N.S. } \\
\text { p2 N.S. } \\
\text { p3 N.S. }\end{array}$ \\
\hline SGPT (U/ml) & $19.87 \pm 1.16$ & $\begin{array}{c}19.75 \pm 2.29 \\
\text { p1 N.S. }\end{array}$ & $\begin{array}{c}20.43 \pm 2.05 \\
\text { p1 N.S. } \\
\text { p2 N.S. }\end{array}$ & $\begin{array}{l}19.92 \pm 2.48 \\
\text { p1 N.S. } \\
\text { p2 N.S. } \\
\text { p3 N.S. }\end{array}$ \\
\hline Triglycerides $(\mathrm{mmol} / \mathrm{L})$ & $1.10 \pm 0.30$ & $\begin{array}{c}1.2812 \pm 0.387 \\
\text { p1 N.S. }\end{array}$ & $\begin{array}{c}1.3152 \pm 0.415 \\
\text { p1 }<0.05 \\
\text { p2 N.S. }\end{array}$ & $\begin{array}{c}1.2190 \pm 0.400 \\
\text { p1 N.S. } \\
\text { p2 N.S. } \\
\text { p3 N.S. }\end{array}$ \\
\hline Total bilirubin $(\mu \mathrm{mol} / \mathrm{L})$ & $8.24 \pm 3.59$ & $\begin{array}{c}11.33 \pm 3.96 \\
\mathrm{p} 1<0.01\end{array}$ & $\begin{array}{c}10.78 \pm 4.51 \\
\text { p1 }<0.05 \\
\text { p2 N.S. }\end{array}$ & $\begin{array}{l}10.76 \pm 4.25 \\
\text { p1 N.S. } \\
\text { p2 N.S. } \\
\text { p3 N.S. }\end{array}$ \\
\hline Pyruvate (mmol/L) & $0.05 \pm 0.02$ & $\begin{array}{c}0.05 \pm 0.02 \\
\text { p1 N.S. }\end{array}$ & $\begin{array}{l}0.06 \pm 0.01 \\
\text { p1 N.S. } \\
\text { p2 N.S. }\end{array}$ & $\begin{array}{l}0.06 \pm 0.01 \\
\text { p1 N.S. } \\
\text { p2 N.S. } \\
\text { p3 N.S. }\end{array}$ \\
\hline Lactate $(\mathrm{mmol} / \mathrm{L})$ & $0.82 \pm 0.33$ & $\begin{array}{c}0.82 \pm 0.37 \\
\text { p1 N.S. }\end{array}$ & $\begin{array}{c}0.86 \pm 0.26 \\
\text { p1 N.S. } \\
\text { p2 N.S. }\end{array}$ & $\begin{array}{c}0.88 \pm 0.26 \\
\text { p1 N.S. } \\
\text { p2 N.S. } \\
\text { p3 N.S. }\end{array}$ \\
\hline Lactate:pyruvate ratio & $18.07 \pm 9.57$ & $\begin{array}{c}15.91 \pm 7.53 \\
\text { p1 N.S. }\end{array}$ & $\begin{array}{c}16.05 \pm 5.81 \\
\text { p1 N.S. } \\
\text { p2 N.S. }\end{array}$ & $\begin{array}{l}14.98 \pm 5.62 \\
\text { p1 N.S. } \\
\text { p2 N.S. } \\
\text { p3 N.S. }\end{array}$ \\
\hline
\end{tabular}

p1: groups versus controls

p2: phenytoin versus other groups

p3: carbamazepine versus phenobarbital group

carnitine after therapy was significantly lower $(\mathrm{P}<0.001)$ than before therapy. Among them, 14 cases showed decreased values $(56 \%)$ after treatment. There was a significant increase in the mean \pm SD values of total bilirubin and lactate after therapy in comparison to that before therapy ( $\mathrm{P}<0.01$ for each). After therapy, 4 out of 25 patients showed elevated values of SGPT $(16 \%)$ and one case showed elevated values of SGOT $(4 \%)$.

In comparison to control values, the mean $\pm \mathrm{SD}$ of free carnitine showed significant decrease $(\mathrm{P}<0.01)$, the values of triglycerides showed significant increase $(\mathrm{P}<0.05)$ (incidence is $32 \%$ ), and the value of total bilirubin showed significant increase $(\mathrm{P}<0.05)$ after therapy (incidence is $20 \%)$. There was a significant negative correlation between the values of carnitine and lactate before $(\mathrm{P}<0.05)$ and after therapy $(\mathrm{P}<$ 
0.01 ), between carnitine and lactate/pyruvate ratio before and after therapy $(\mathrm{P}<0.05$ for each).

Group III (Phenobarbital Treated Cases): The values of mean \pm SD of serum free carnitine after therapy was significantly lower than that before therapy $(\mathrm{P}<0.01)$. Among them, three cases showed decreased values (30\%) after treatment and in spite of that, no significance was detected in comparison to controls.

The patients had a mean \pm SD values of SGOT and SGPT after therapy higher than that before therapy and this increase was significant $(\mathrm{P}<0.05$ for each). Also, a significant increase was observed in the values of pyruvate after therapy in comparison to that before therapy $(\mathrm{P}<0.01)$, but this difference in values was statistically insignificant in comparison to that of control.

In comparison between the values of all the studied cases after therapy and those of controls, there was a significant decrease of serum free carnitine $(\mathrm{P}<0.01)$ while triglycerides and bilirubin values were significantly increased $(\mathrm{P}<0.05$ for each) (Tables 3 and 4) (Fig. 1).

TABLE 3. The mean \pm SD of the various parameters studied in the sera of all epileptic cases before therapy in comparison to controls.

\begin{tabular}{|l|c|c|c|}
\hline \multicolumn{1}{|c|}{ Parameter } & $\begin{array}{c}\text { Controls } \\
(\mathrm{n}=20)\end{array}$ & $\begin{array}{c}\text { All Cases } \\
(\mathrm{n}=60)\end{array}$ & $t$-test \\
\hline Free carnitine $(\mu \mathrm{mol} / \mathrm{L})$ & $44.50 \pm 2.42$ & $47.10 \pm 11.53$ & N.S. \\
\hline SGOT $(\mathrm{U} / \mathrm{ml})$ & $20.45 \pm 3.30$ & $20.13 \pm 2.19$ & N.S. \\
\hline SGPT $(\mathrm{U} / \mathrm{ml})$ & $19.87 \pm 1.16$ & $19.62 \pm 2.36$ & N.S. \\
\hline Triglycerides $(\mathrm{mmol} / \mathrm{L})$ & $1.10 \pm 0.30$ & $1.17 \pm 0.36$ & N.S. \\
\hline Total bilirubin $(\mu \mathrm{mol} / \mathrm{L})$ & $8.24 \pm 3.59$ & $9.74 \pm 4.22$ & N.S. \\
\hline Pyruvate $(\mathrm{mmol} / \mathrm{L})$ & $0.05 \pm 0.02$ & $0.05 \pm 0.01$ & N.S. \\
\hline Lactate $(\mathrm{mmol} / \mathrm{L})$ & $0.82 \pm 0.33$ & $0.79 \pm 0.25$ & N.S. \\
\hline Lactate:pyruvate ratio & $18.07 \pm 9.57$ & $16.03 \pm 6.61$ & N.S. \\
\hline
\end{tabular}

No significant correlation was found between serum free carnitine and liver enzymes in any group except in controls, where a significant negative correlation was observed between serum free carnitine and each GOT values $(\mathrm{R}=0.4, \mathrm{P}<0.05)$ and bilirubin values $(\mathrm{r}=0.39, \mathrm{P}<0.05)$. In addition, no significant correlation was found in the present study between serum free carnitine and the children's ages.

\section{Discussion}

Epilepsy is a frequently encountered condition among the attending patients in any ten influences the choice of drugs or limits the success of drug therapy. Since most pa- 
TABLE 4. The mean \pm SD of the various parameters studied in the sera of all epileptic cases after therapy in comparison to controls.

\begin{tabular}{|l|c|c|c|}
\hline \multicolumn{1}{|c|}{ Parameter } & $\begin{array}{c}\text { Controls } \\
(\mathrm{n}=20)\end{array}$ & $\begin{array}{c}\text { All Cases } \\
(\mathrm{n}=60)\end{array}$ & $t$-test \\
\hline Free carnitine $(\mu \mathrm{mol} / \mathrm{L})$ & $44.50 \pm 2.42$ & $38.50 \pm 12.60$ & $<0.01$ \\
\hline SGOT $(\mathrm{U} / \mathrm{ml})$ & $20.45 \pm 3.30$ & $20.93 \pm 2.27$ & N.S. \\
\hline SGPT $(\mathrm{U} / \mathrm{ml})$ & $19.87 \pm 1.16$ & $20.06 \pm 2.21$ & N.S. \\
\hline Triglycerides $(\mathrm{mmol} / \mathrm{L})$ & $1.10 \pm 0.30$ & $1.29 \pm 0.40$ & $<0.05$ \\
\hline Total bilirubin $(\mu \mathrm{mol} / \mathrm{L})$ & $8.24 \pm 3.59$ & $11.01 \pm 4.18$ & $<0.05$ \\
\hline Pyruvate $(\mathrm{mmol} / \mathrm{L})$ & $0.05 \pm 0.02$ & $0.06 \pm 0.01$ & N.S. \\
\hline Lactate $(\mathrm{mmol} / \mathrm{L})$ & $0.82 \pm 0.33$ & $0.84 \pm 0.31$ & N.S. \\
\hline Lactate:pyruvate ratio & $18.07 \pm 9.57$ & $15.91 \pm 7.53$ & N.S. \\
\hline
\end{tabular}

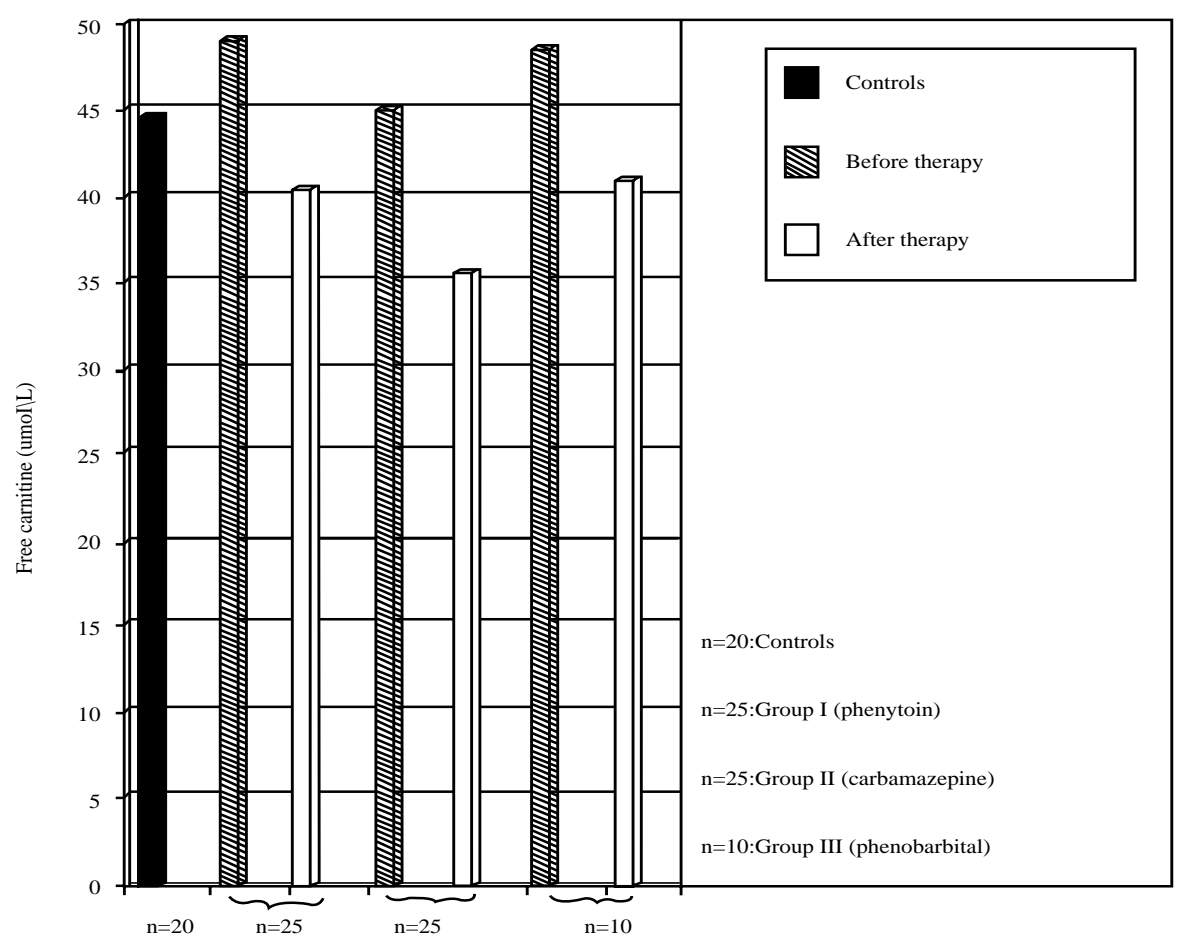

Fig. 1: Plasma free carnitine levels in different groups of patients and controls before and after therapy. 
tients undergo long-term treatment with these drugs, detection of chronic toxicity is of special importance ${ }^{[18]}$.

With the use of anticonvulsants there is a risk of developing secondary carnitine deficiency which is claimed to induce Reye-like syndrome involving stupor, coma, encephalopathy, hepatic dysfunction, and hyperammonemia ${ }^{[6,22,23]}$.

Carnitine is an important nutrient that is present in the diet and is synthesized from dietary amino acids. It functions to assist long chain fatty acid metabolism and to regulate the ratio of free coenzyme-A to acylcoenzyme-A in the mitochondrion. Carnitine deficiency occurs in primary inborn errors of metabolism, in nutritional deficiency, and in various other disorders including antiepileptic drug therapy ${ }^{[13,18]}$.

Taking the mean 2-SD of control values as a lower limit of normal, the present study showed that there is a decrease in the mean values of serum free carnitine in all the studied groups after therapy in comparison to pretreatment levels. Twenty-eight percent of group I, $56 \%$ of group II, and $30 \%$ of group III studied patients showed a significant decrease in free carnitine level after treatment. Meanwhile, a significant decrease was observed in the second group $(\mathrm{P}<0.01)$ in comparison to controls.

These findings indicate that carbamazepine has the greatest effect on carnitine in comparison to other antiepileptic drugs. Previous reports of Morita $e a{ }^{[24]}$, Segade et $a l^{[18]}$, and Beghi et $a l^{[25]}$ support these findings. In the study of Segade et $a l^{[18]}$, they found that the groups treated with carbamazepine and phenobarbital had free carnitine concentration less than those of controls. They detected hypocarnitinemia in $21.5 \%$ of their studied patients. In the study of Beghi et al ${ }^{[25]}$, they reported that carnitine deficiency, which is produced with these antiepileptic drugs, is worth noting and may be a part of a more general biochemical effect of antiepileptic drug therapy on lipid metabolism. However, the significant hypocarnitinemia found in the present study was not detected in the study of Ohtani et $a l^{[6]}$ and Sugimoto et al ${ }^{[11]}$.

The mechanism by which these drugs cause carnitine deficiency is still not clear and is a field for further studies. According to Ohtani et al ${ }^{[6]}$, the enhanced consumption of carnitine, inhibition of carnitine synthesis, and increased excretion of carnitine could be the cause of hypocarnitinemia. Coulter ${ }^{[13]}$ proposed that carnitine deficiency in patients with epilepsy may result from pre-existing metabolic disorders, nutritional inadequacy, pharmacological effects of the drugs, or a combination of these factors.

Other investigators attributed carnitine deficiency in these patients to the sequestration of free $\mathrm{CoA}^{[11,12]}$, inhibition of $\beta$-oxidation enzymes ${ }^{[13]}$ by drug metabolites, and recently to the decreased level of L-glutamate and L-ketoglutarate ${ }^{[16]}$ in liver due to antiepileptic drug intake.

The present study supports the contention of the previous investigators that the development of secondary carnitine deficiency is related to the anticonvulsant therapy. 
Another finding obtained in the present work was the significant increase in the mean values of serum triglycerides in all patients in comparison to controls $(\mathrm{P}<0.05)$. The significantly increased triglycerides values are detected mainly in the carbamazepine treated group $(\mathrm{P}<0.05)$. This finding is in accordance with that of Datsur and Dave [26]. The possible mechanism of the increased level of triglycerides is the inhibition of $\beta$-oxidation of fatty acids due to carnitine deficiency and as a result, the fatty acids will be directed to triglyceride synthesis ${ }^{[27]}$.

Moreover, in the present study, there is a significant increase in the mean values of total bilirubin after therapy in comparison to that before therapy $(\mathrm{P}<0.05)$ and in relation to controls $(\mathrm{P}<0.01$ and $\mathrm{P}<0.05)$ in both group I and II, respectively. This is supported by the finding of Beghi et al ${ }^{[25]}$. In addition, a significant increase of the mean values of GOT in the sera of phenytoin treated cases $(\mathrm{P}<0.001)$ and GPT in the sera of phenobarbital treated cases $(\mathrm{P}<0.05)$ after, in comparison to that before therapy. This finding is supported by the reports of Aldenhovel ${ }^{[28]}$ and Sugimoto et al ${ }^{[11]}$. Also, the increase in the mean values of pyruvate in phenobarbital treated cases $(\mathrm{P}<$ $0.01)$ and lactate in carbamazepine treated cases $(\mathrm{P}<0.01)$ after, in relation to that before, therapy is in accordance with the findings of Thurston et al ${ }^{[29]}$ and Sugimoto $e t$ $a l^{[30]}$.

Interestingly, in the present study, there is a negative correlation between carnitine and lactate and lactate/pyruvate ratio in the carbamazepine group after therapy. This can be explained by the increased rate of anaerobic glycolysis in a trial to overcome the shortage in energy with the resulting risk of lactic acidosis. At the same time Krebs cycle may be inhibited by the resulting high level of $\mathrm{NADH}+\mathrm{H}^{+}$. In turn, ketoglutarate levels may be decreased which has been proven to be the cofactor for carnitine precursor hydroxylation leading to carnitine depletion and more worsening of the condition. This explanation is recently supported by Farkas et al ${ }^{[16]}$. These findings, together with the increased incidence of carnitine depletion $(56 \%)$ in the same group, significantly increased levels of serum lactate, triglycerides, total bilirubin, and GPT after carbamazepine treatment suggest the more severe impact of carbamazepine on carbohydrate and fatty acid metabolism as well as liver function as a whole.

Furthermore, the present study revealed that the epileptic children under treatment with antiepileptic drugs have the risk of developing secondary carnitine deficiency. This hypocarnitinemia by itself would not produce an acute illness, but it could render these children susceptible to a critical, even fatal, disease when it is accompanied by a metabolic load mainly on the fatty acid metabolism ${ }^{[3,31]}$.

The previous studies showed a significant negative correlation between plasma carnitine and blood ammonia values following oral carnitine administration ${ }^{[32]}$ and that carnitine administration resulted in clinical improvement of recurrent Reye-like syndrome with systemic carnitine deficiency ${ }^{[32]}$. On the other hand, Ishikura et al ${ }^{[33]}$ recommended L-carnitine supplementation to prevent potentially fatal hepatic dysfunc- 
tion after valproic overdose. In addition, Therrien et al ${ }^{[34]}$ reported that L-carnitine could be of therapeutic benefit in the prevention of hepatic encephalopathy precipitated by ammoniagenic conditions in humans with chronic liver disease.

Young children have a reduced capacity for carnitine biosynthesis which may limit their ability to compensate for antiepileptic drug-induced carnitine depletion. Children with neurologic disabilities, especially, may have an underlying primary carnitine deficiency due to an unrecognized inborn error of metabolism ${ }^{[13]}$. So, it is now recognized that the endogenous biosynthesis alone is not sufficient to keep carnitine concentration at an adequate level $^{[35]}$.

Therefore, physicians who prescribe anticonvulsants, especially carbamazepine, for epileptic children must pay careful attention to the possible side effects that may occur. It is more logical to supply these children with carnitine-rich foods in the form of milk or milk products as a supplement to antiepileptic therapy to meet their carnitine needs and to guard against metabolic consequences of its probable deficiency.

\section{References}

[1] Ward AA Jr, Penry IK, Pupura D (Editors). Epilepsy. New York: Raven Press, 1983.

[2] Mattson RH, Cramer JA, Collins JF. Comparison of carbamazepine, phenobarbital, and primidone in partial and secondarily generalized tonic clonic seizures. N Engl J Med 1985; 313: 145-152.

[3] Gerber N, Dickinson RG, Harland RC, Lynn PK, Houghton LD, Antonias JI, Schimschock JC. Reye like syndrome associated with valproic acid therapy. J Pediatr 1979; 95: 142-144.

[4] Young RSK, Bergman I, Gang DL, Richardson EP. Fatal Reye-like syndrome associated with valproic acid. Ann Neurol 1980; 7: 389.

[5] Coulter DL, Allen RJ. Hyperammonemia with valproic acid therapy. J Pediatr 1981; 99: 317-319.

[6] Ohtani Y, Endo F, Matsuda I. Carnitine deficiency and hyperammonemia associated with valproic acid therapy. J Pediatr 1981; 101: 782-785.

[7] Matsuda I, Ohtani Y, Ninomiya N. Renal handling of carnitine in children with carnitine deficiency of hyperammonemia associated with valproate therapy. J Pediatr 1986; 109: 131-134.

[8] Hiraoka A, Arato T, Tominaga I. Reduction in blood free carnitine levels in association with changes in VPA disposition in epileptic patients treated with VPA and other antiepileptic drugs. Biol Pharm Bull 1997; 20(1): 91-93.

[9] Coude FX, Rabier O, Cathelineau L, Grimber G, Parvy P, Kamoun PP. A mechanism for valproate induced hyperammonemia. Pediatr Res 1981; 15: 974-975.

[10] Haas R, Stumpf DA, Parks JK, Eguren L. Inhibitory effects of sodium-valproate on oxidative phosphorylation. Neurology 1981; 13: 1473-1476.

[11] Sugimoto T, Woo M, Nishida N, Takeuchi T, Sakane Y, Kobayashi Y. Hepatotoxicity in rat following administration of valproic acid. Epilepsia 1987; 28(2): 142-146.

[12] Rozas I, Camina MF, Paz JM, Alonso C, Castro-Gago M, Rodriguez-Senegale S. Effect of acute valproate administration oncarnitine metabolism in mouse serum and tissues. Biochem Pharmacol 1990; 93: 181-185.

[13] Coulter ID. Carnitine, valproate, and toxicity. J Child Neurol 1991; 6: 7-14.

[14] Kesterson JW, Granneman GR, Machinist JM. The hepatotoxicity of valproic acid and its metabolites in rats. I. Toxicologic, biochemical, and histopathologic studies. Hepatology 1984; 4(6): 1143-1152.

[15] Levy RH, Rettenmeier AW, Anderson GD, Wilensky Aj, Friel PN, Baillie TA, Acheampong A, Tor J, Guyot M, Loiseau P. Effects of polytherapy with phenytoin, carbamazepine, and stiripentol on formation of 4-ene-valproate, a hepatotoxic metabolite of valproic acid. Clin Pharmacol Ther; 
48(3): 225-235.

[16] Farkas V, Bock I, Cseko J, Sandor A. Inhibition of carnitine biosynthesis is by valproic acid in rats. The biochemical mechanism of inhibition. Biochem Pharmacol 1996; 52(9): 1429-1433.

[17] Matsuda I, Ohtani Y. Carnitine status in Reye and Reye-like syndrome. Pediatr Neurol 1986; 2(2): 90-94.

[18] Rodriguez-Segade RS, de la Penta CA, Tutor JC, Paz JM, Fernandez MP, Rozas I, Del Rio R. Carnitine deficiency associated with anticonvulsant therapy. Clin Chim Acta 1989; 181(2): 175-181.

[19] Bates SR, Hug G. Carnitine reduction and anticonvulsants in children. Ann Neurol 1989; 26: 468469.

[20] Reitman S, Frankle S. Colorimetric determination of GOT and activity. Am J Clin Path 1957; 28: 56.

[21] Marbach EP, Weil MH. Rapid enzymatic determination of blood lactate and pyruvate. J Clin Chem 1967; 13(4): 314-325.

[22] Coulter DL. Carnitine deficiency: a possible mechanism for valproate hepatotoxicity. Lancet 1984; 1(8378): 689.

[23] Murphy JV, Marquardt KM, Shug AL. Valproic acid associated abnormalities of carnitine metabolism. Lancet 1985;1(8342): 820-821.

[24] Morita J, Yuge K, Yoshino M. Hypocarnitinemia in the handicapped individuals who receive a polypharmacy of antiepileptic drugs. Neuropediatrics 1986; 17(4): 203-205.

[25] Behgi E, Bizzi A, Codegoni AM, Trevisan D, Torri W, Collaborative Group for the Study of Epilepsy. Valproate, carnitine metabolism, and biochemical indicators of liver function. Epilepsia 1990; 3: 346-352.

[26] Datsur SK, Dave UP. Effect of prolonged anticonvulsant medication in epileptic patients: serum lipids, vitamins B6, B12 and folic acid, proteins, and fine structure of liver. Epilepsia 1987; 28(2): 147-159.

[27] Laub MC, Paetzke-Brunner IP, Jaeger G. Serum carnitine during valproic acid therapy. Epilepsia 1986; 27(5): 559-562.

[28] Aldenhuvel HG. The influence of long term anticonvulsant therapy with DPH and carbamazepine on serum gamma glutamyl transferase, aspartate aminotransferase, alanine aminotransferase, and alkaline phosphatase. Eur Arch Psychiatry Neurol Sci 1988; 237(5): 312-316.

[29] Thurston JH, Carroll JE, Hauhart RE, Schiro JA. A single therapeutic dose of valproate effects, liver carbohydrate, fat, adenylate, amino acid, coenzyme A, and carnitine metabolism in infant mice: 1c- possible clinical significance. Life Sci 1985; 36(17): 1643-1651.

[30] Sugimoto T, Nishida N, Woo M, Takeuchi T, Yasuhara A, Kobayashi Y, Sakane Y. Serum and urinary carnitine and organic acids in Reye syndrome and Reye-like syndrome. Brain Dev 1986; 8 (3): $257-261$.

[31] Bohles H, Richter K, Wagner-Thiessen E, Schafer H. Decreased serum carnitine in valproate induced Reye syndrome. Eur J Pediatr 1982; 139(3): 185-186.

[32] Chapoy PR, Angelini C, Brown WJ, Stiff JE, Shug AL, Cederbaum SD. Systemic carnitine deficiency. A treatable inherited lipid storage disease presenting as Reye's syndrome. N Engl J Med 1980; 303(24): 1389-1393.

[33] Ishikura H, Matsuo N, Matsubara M, Ishihara T, Takeyama N, Tanaka T. Valproic acid overdose and L-carnitine therapy. J Anal Toxicol 1996; 20(1): 55-58.

[34] Therrien G, Rose C, Butterworth J, Butterworth RF. Protective effect of L-carnitine in ammonia precipitated encephalopathy in the portocaval shunted rat. Hepatology 1997; 25(3): 551-556.

[35] Rebouche CJ, Paulson DJ. Carnitine metabolism and function in humans. Annu Rev Nutr 1986; 6: 41-66. 


\section{تقييم حالة الكارنيتين ووظائف الكبد في الأطفال الذين يعالجون بأدوية الصرع}

سعاد عبد الغني * ، تحية سليم *** محمد غزالي ****، و نجلاء المليجي كاء *قسم الكيمياء الحيوية السريرية، كلية الطب و العلوم الطبية، جامعة الملك عبدالعزيز،

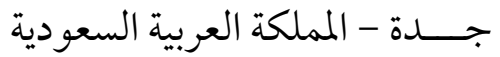

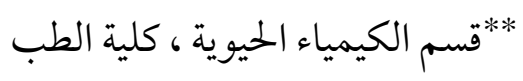

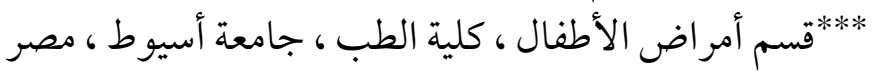

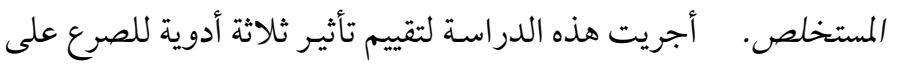

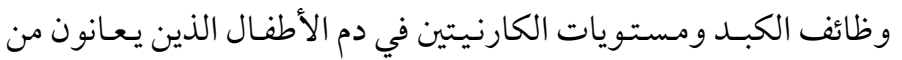

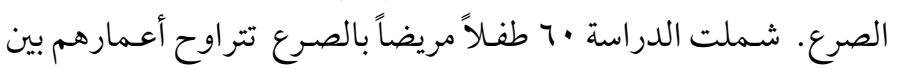

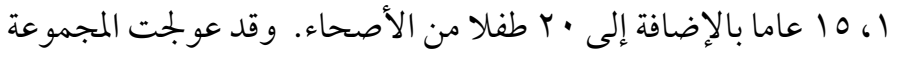

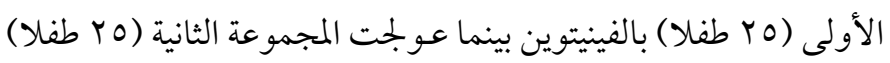

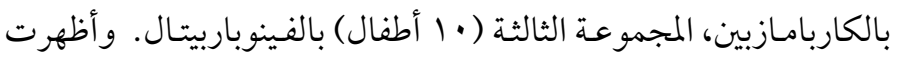

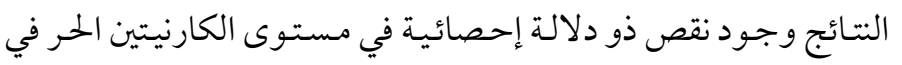

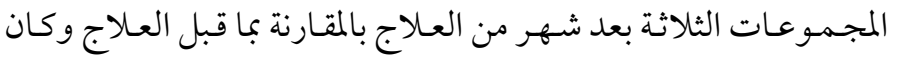

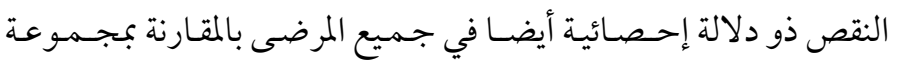

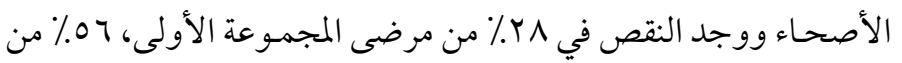

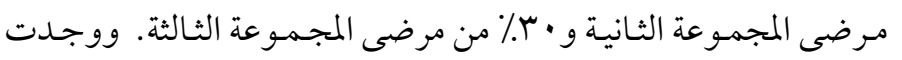

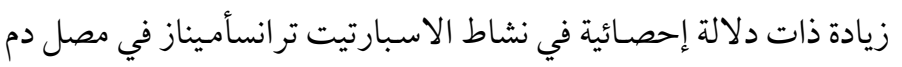

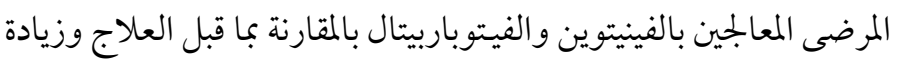

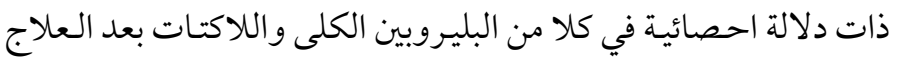

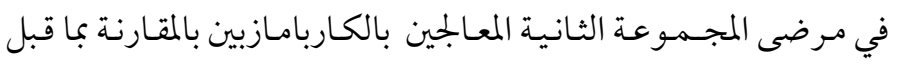

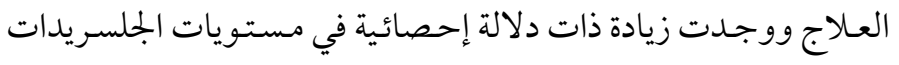
الثلاثية والبيليروبين الكلى في جميع المرضى بالمقارنة بجمهو عادة الأصحاء.

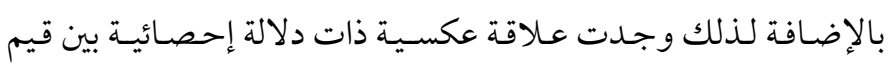


الكارنيتين وكلا من اللاكتات، ونسبة اللاكتات إلى البيروفات بعد العلاج

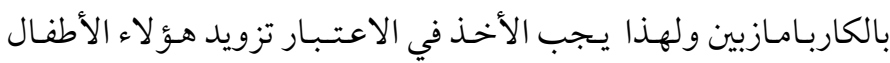

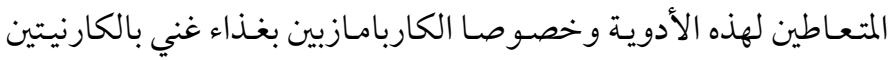

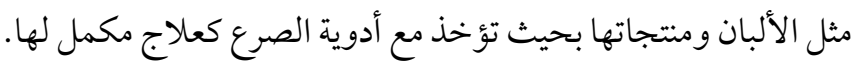

